\title{
Abnormal Orgasm
}

National Cancer Institute

\section{Source}

National Cancer Institute. Abnormal Orgasm. NCI Thesaurus. Code C78510.

A change in the ability to obtain orgasm or in the quality of the orgasmic sensation. 